\title{
Sources markers in aerosols, oceanic particles and sediments
}

A. Saliot ${ }^{\mathrm{a}}$

Laboratoire LOCEAN, IPSL/UPMC/UMR CNRS 7159, 4 place Jussieu, 75252 Paris Cedex 05, France

\begin{abstract}
This review presents some diagnostic criteria used for identifying and quantifying terrestrial organic matter inputs to the ocean. Coupled to the isotopic composition of total organic carbon, the analysis of stable biomarkers permits to trace higher plant contributions in aerosols, dusts, sedimenting particles and dissolved phase in the water column and ultimately in recent and ancient sediments and soils. Some applications are presented, based on the analysis of n-alkyl compounds by a combination of gas chromatography and mass spectrometry (n-alkanes, n-alkanols, n-alkanoic acids and wax esters). Another approach has been developed using the analysis of macromolecular compounds present in higher plants. Abundances of the phenolic compounds from lignin, benzene carboxylic acids obtained during cupric oxide oxidation, Curie pyrolysis are used to characterise terrestrial organic matter sources and inputs. Finally due to the importance of biomass burning in continent-ocean transfers, biomarkers are presented in the polycyclic aromatic hydrocarbon class and for monosaccharide derivatives from the breakdown of cellulose.
\end{abstract}

\section{Introduction}

The role of the ocean in regulating the climate is major owing to its surface, approximately $4 / 5$ of the earth's surface, and as it is one of the major reservoir of an element connected to the greenhouse effect and to the development of marine and terrestrial life, the carbon [1].

One of the major goal for geochemists is to better know the functioning of the carbon cycle and the role of the ocean in atmospheric $\mathrm{CO}_{2}$ pumping [2,3]. There is an excess of the ocean pumping, which can be decomposed into a physical pump (dissolution and transport of $\mathrm{CO}_{2}$ into the deep ocean in zones of formation of deep waters, Greenland and Norwegian Seas in the Arctic, Labrador Sea in the Atlantic, Weddell Sea in the Antarctic) and a biological pump based on the process of photosynthesis.

The ocean is characterized by an original organic carbon cycle, in interaction with the huge dissolved inorganic carbon pool [3]. By decreasing order of importance are: i) the dissolved (and colloidal) organic carbon pool with a stock of 1000 Gigatonnes of Carbon (GtC), which is the most important reservoir of organic carbon at the earth's surface. This organic carbon is relatively chemically inert, with a long residence time in deep waters of the Atlantic and the Pacific, $\sim 3000$ years. But in surface waters it is biologically labile and constitutes a large reservoir of energy for heterotrophic organisms; ii) the particulate organic pool (POC), with $30 \mathrm{GtC}$, major actor in sedimentation processes, slow with small-size settling particles and rapid with large-size $(>50-60 \mu \mathrm{m})$ sinking particles and iii) the biomass carbon, which integrates all living organisms, from the virus to large mammals, with a modest pool of $3 \mathrm{GtC}$. Thus the size of marine biota carbon reservoir is much smaller than the fluxes in and out the reservoir. This implies that any changes in the activity of this reservoir can mean substantial changes

\footnotetext{
a e-mail: alain.saliot@upmc.fr
} 
in the fluxes to related reservoirs, such as the burial of particulate organic carbon in marine sediments.

Carbon fluxes are estimated as follows: the major flux, $50 \mathrm{GtC} /$ year, is from the oceanic net biological production. A small part of this net flux, $0.2 \mathrm{GtC} /$ year, will be incorporated in sediment, after complex sedimentation processes. Natural inputs from the continent carried out by rivers and steams are in the range of $0.4 \mathrm{GtC} /$ year, whereas vegetation emits organic material, both in gas phase and in small submicronic particles which a part, estimated in the range $1-1.5 \mathrm{GtC} /$ year, is introduced in the ocean by direct deposition and washout of the atmosphere $[2,3]$.

A goal of many organic geochemical studies is to determine the sources and relative proportions of organic matter in the material carried out between the continent and the ocean, in dusts, aerosols, living and non living sedimenting particles, dissolved and colloidal phase and sediments (Fig. 1). Several tools exist and have been extensively used throughout many studies: isotopic composition of total organic carbon [4] or of individual compounds determined from isotope ratio monitoring gas chromatography-mass spectrometry (IRM GC-MS) [5], analysis of lignin-derived compounds [6,7], analysis of lipid biomarkers by GC-MS, providing the ability to distinguish between algal, bacterial and vascular plant sources and thus a broad scope of organic source interpretation $[8,9]$.

\section{Biomakers for terrestrial organisms and transport mechanisms}

\section{1 n-Alkyl compounds}

\subsubsection{A large choice of biomarkers}

Long-chain n-alkyl compounds are major components of epicuticular waxes from vascular plant leaves. These compounds are relatively stable in the environment and resistant to degradation, which makes them suitable for use as higher plant biomarkers.

They include n-alkanes (I), n-alkanols (II), n-alkanoic acids (III) and was esters (IV), (Fig. 2).

All four compound classes have been identified in recent and ancient terrestrial and marine sediments [5,10], soils of crop fields and fugitive dust [11] and n-alkanes in aerosols [12,13]. n-Alkanes occur in higher plants, where they typically have carbon-chain lengths, from $\mathrm{C}_{25}$ to $\mathrm{C}_{35}$ and a strong predominance of odd-carbon number homologues, $\mathrm{C}_{27}, \mathrm{C}_{29}, \mathrm{C}_{31}$, over evennumbered ones. These high molecular-weight n-alkanes are more resistant to degradation than shorter-chain homologues and other n-alkyl components, the order of stability decreasing in the order: n-alkanes, n-alkanoic acids, n-alkanols.

\subsubsection{Applications}

2.1.2.1. The pioneer work for tracing terrestrial organic inputs by dusts to the ocean. Since the pioneer work performed by Simoneit [12] using lipid biomarkers to quantify terrestrial inputs from eolian dusts to the open Atlantic Ocean, this tool is very commonly used, e.g. [13], and references therein. The lipids of eolian dusts sampled from the air mass over the eastern Atlantic from about $35^{\circ} \mathrm{N}$ to $30^{\circ} \mathrm{S}$ were analysed [12]. These lipids consisted mainly of n-alkanes, $\mathrm{n}$-alkanoic acids and n-alkohols. The n-alkanes were found to range from n- $\mathrm{C}_{23}$ to $\mathrm{n}-\mathrm{C}_{35}$, with high odd-carbon number homologues predominance and maximizing at $\mathrm{n}-\mathrm{C}_{27}$ in the North Atlantic, at $\mathrm{n}-\mathrm{C}_{29}$ in the equatorial Atlantic and at $\mathrm{n}-\mathrm{C}_{31}$ in the South Atlantic. The n-alkanoic acids had mostly bimodal distributions, ranging from $n-\mathrm{C}_{12}$ to $n-\mathrm{C}_{30}$, with maxima at $\mathrm{n}-\mathrm{C}_{16}$ and in the northern samples at $\mathrm{n}-\mathrm{C}_{24}$ and in the southern samples at $\mathrm{n}-\mathrm{C}_{26}$. The $\mathrm{n}$-alkanols ranged from $\mathrm{n}-\mathrm{C}_{12}$ to $\mathrm{n}-\mathrm{C}_{32}$, with a high odd-carbon numbered homologues predominance and maxima mainly at $n-C_{28}$. The compositions of these lipids indicated that their terrigenous sources were comprised mainly of higher plant vegetation and dessicated lacustrine mud flats of the African continent. 


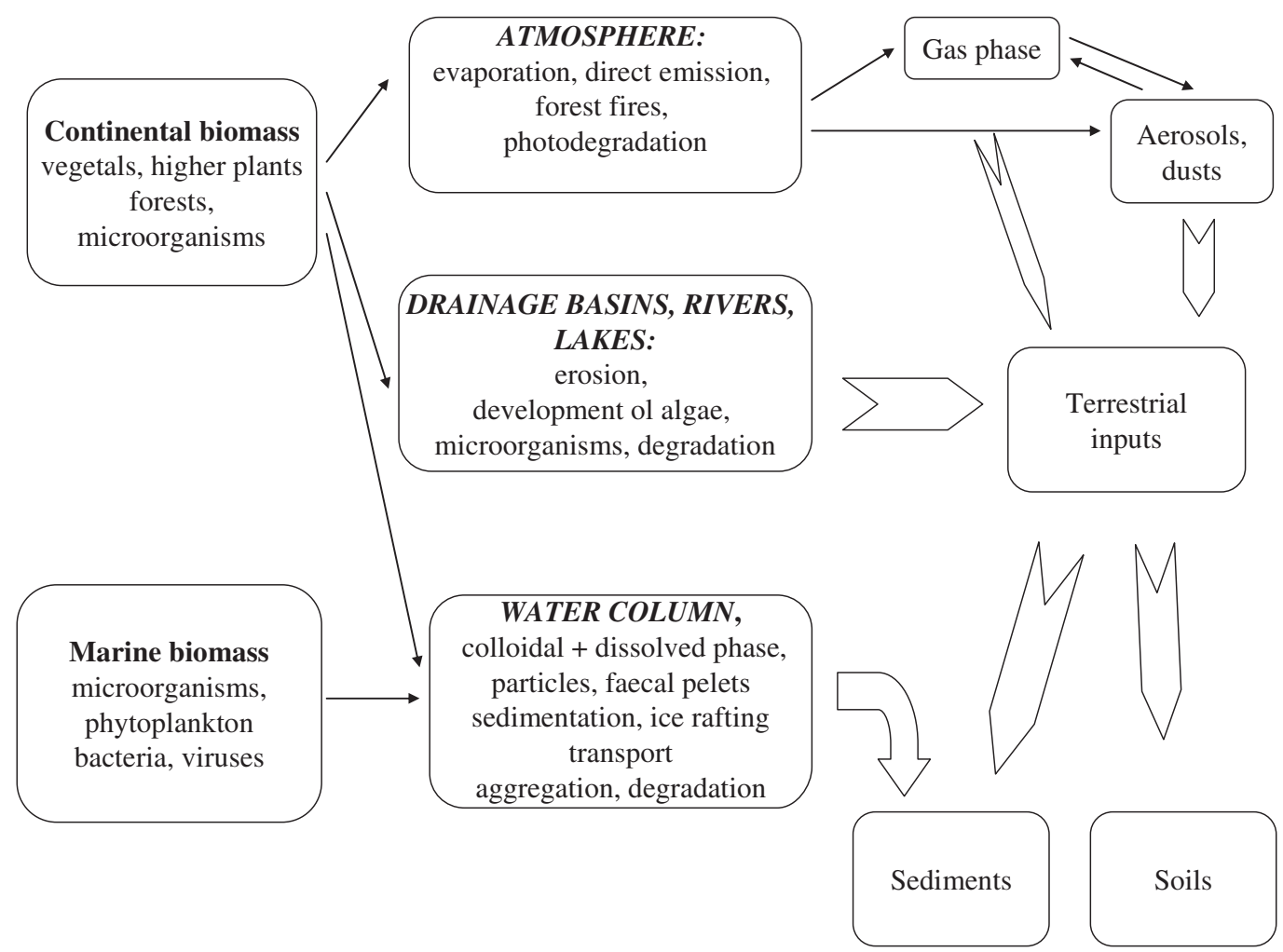

Fig. 1. Representation of exchanges of terrestrial and marine material between the continent and the ocean and associated biological and chemical processes.

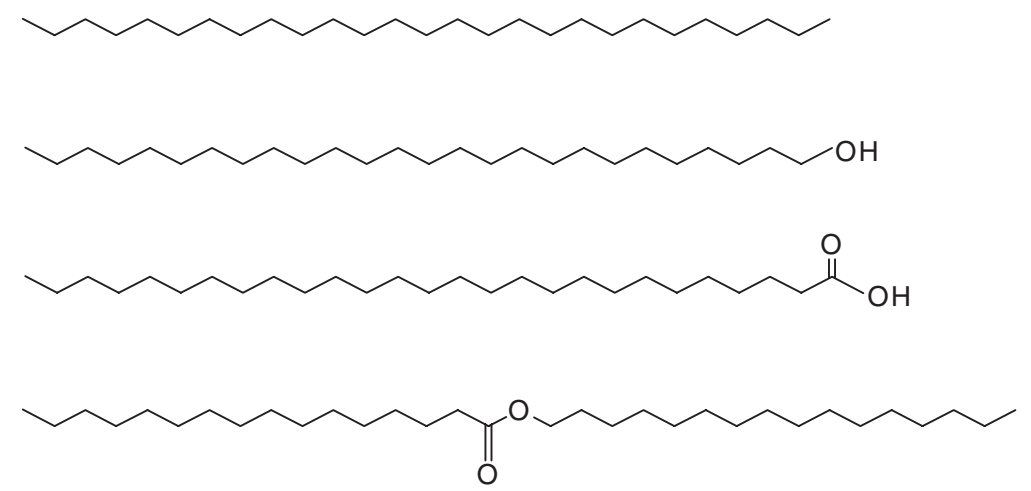

Fig. 2. Structures of alkyl compounds commonly found in terrestrial plants. I: n-alkane; II: n-alkanol; III: n-alkanoic acid; IV: wax ester.

2.1.2.2. Evidencing terrigenous organic matter inputs associated with turbidites. The initial goal of the study performed by Treignier et al. [14] was to study the sedimentary systems on the West African continental margin and the benthic ecosystem of the Zaire canyon in relation to organic matter inputs, as the quantity and quality might influence its development. Two criteria were used: the relative abundance of short $\left(<\mathrm{C}_{20}\right)$ and long-chain $\left(>\mathrm{C}_{22}\right)$ n-alkohols derived from marine organisms and higher plants, respectively, and the ratio of odd to evencarbon numbered $<\mathrm{C}_{20}$ n-alkohols to assess the extent of alteration. The strong link between the Zaire River and the deep sea sediments was shown via the turbidity currents composition. 
Turbidity currents carry huge amounts of material down to the deep sea several hundred kilometres off the shelf and up to several tens of kilometres outside the main channel. The turbidity overflow evidenced from particles collected in sediment traps remain confined above the bottom in a $<400 \mathrm{~m}$ thick layer. The organic matter of a major turbiditic overflow had a strong terrigenous signal compared with the composition of the particles sinking from surface waters. Its influence was also visible in the surficial sediments of the channel levees, in the total organic composition content as well as in the n-alkohol composition. These regular inputs were suspected to sustain the particular ecosystem encountered in the abyssal plains $(<5000 \mathrm{~m})$ of the Congo-Angola margin. The organic matter quantity and quality (marine versus terrestrial and fresh versus degraded) might influence the development of the benthic ecosystem. The organic matter delivered by the turbidity currents was already much altered. Nevertheless, it was further degraded within the top sediment. The estimated degradation rate constants compared better with incubation experiments than with down core modelling. The early diagenesis in the fluffy layer and the 0.5 -cm thick surficial sediment was very intense, despite the predominance of terrigenous compounds resistant towards degradation.

2.1.2.3. Evidencing terrigenous organic matter inputs at the river/ocean interface. Few studies have examined the composition of organic carbon across the coastal margin from the Mississippi River mouth to the shelf, and out to the more distal slope and canyon environments of the Gulf of Mexico. Most have relied on lignin, and recently on lipid biomarkers in the $\mathrm{n}$-alkanol series and stable carbon isotopic composition $\delta^{13} \mathrm{C}_{\mathrm{TOC}}$ [15]. Organic carbon content decreased fourfold from the marsh to the offshore sites, with corresponding changes in organic matter sources. Biomarkers representing allochthonous (higher plant) and autochthonous (algal/plankton/bacteria) sources demonstrated regional differences in the sources of sediment organic matter. A two end member mixing model using $\delta^{13} \mathrm{C}_{\mathrm{TOC}}$ indicated that C3 vascular plant sources comprised $\sim 80 \%$ and $50 \%$ of the TOC at the river and marsh sites, respectively. However, sources of sedimentary organic matter differed in these regions, with contributions of soil organic matter/terrigenous plant sources dominant in the river $\left(\delta^{13} \mathrm{C}_{\mathrm{TOC}}=-25 \%\right.$ o while marsh plants likely contributed to the enriched signatures found in the marsh sediments $\left(\delta^{13} \mathrm{C}_{\mathrm{TOC}}=-18 \%\right.$ ). Allochthonous organic matter contributions from $\mathrm{n}$-alkanol and sterol biomarkers in the river and marsh regions (39-48\% and 50-72\%, respectively) differed from those determined using $\delta^{13} \mathrm{C}_{\mathrm{TOC}}$. The authors explained this discrepancy to overlapping values for vascular plants and freshwater microalgae and the higher lipid content of the autochthonous sources. Although biomarkers representing terrigenous sources decreased with distance offshore, they comprised approximately 17-34\% of the n-alkanols and sterols at even the most distal slope and canyon sites, suggesting that these deeper regions could be an important sink for terrigenous carbon. In contrast, the shelf sites were enriched in algal material (60-78\% autochthonous organic carbon), with biomarkers for diatoms dominating, suggesting that terrigenous carbon is either diluted in, or bypasses, this region.

2.1.2.4 Evidencing organic matter sources in an enclosed coastal inlet. Volkman et al. [16] recently published a nice study about the sources of organic matter in surface sediments from Wilson Inlet, an enclosed and seasonally barred inlet in Western Australia, using a combination of lipid biomarkers (including n-alkanoic acids and n-alkohols, among other markers) and stable carbon isotope data for bulk organic matter and $\delta^{13} \mathrm{C}$ data for $\mathrm{n}$-alkohols. The organic composition of sediments from the inflowing rivers was used as a proxy for terrestrial inputs of higher plant organic matter, since these sediments contained only small amounts of carbon from microalgae (mostly diatoms), bacteria and cyanobacteria. Thus the relative proportions of "marine" and "terrestrial" organic matter in sediments could be estimated using the stable carbon isotope signature of the bulk organic carbon. The sediments from Wilson Inlet showed similar lipid compositions and isotope values and the sterol and n-alkanoic acid distributions showed the complexity typical of marine ecosystems. Relative contributions from algal, bacterial, terrestrial plants and seagrass sources were estimated using biomarker/organic carbon ratios in the different source terms. The distributions, abundances and $\delta^{13} \mathrm{C}$ isotope values of long-chain n-alkohols proved to be useful in quantifying the contributions from terrestrial plants and the seagrass Ruppia megacarpa. 


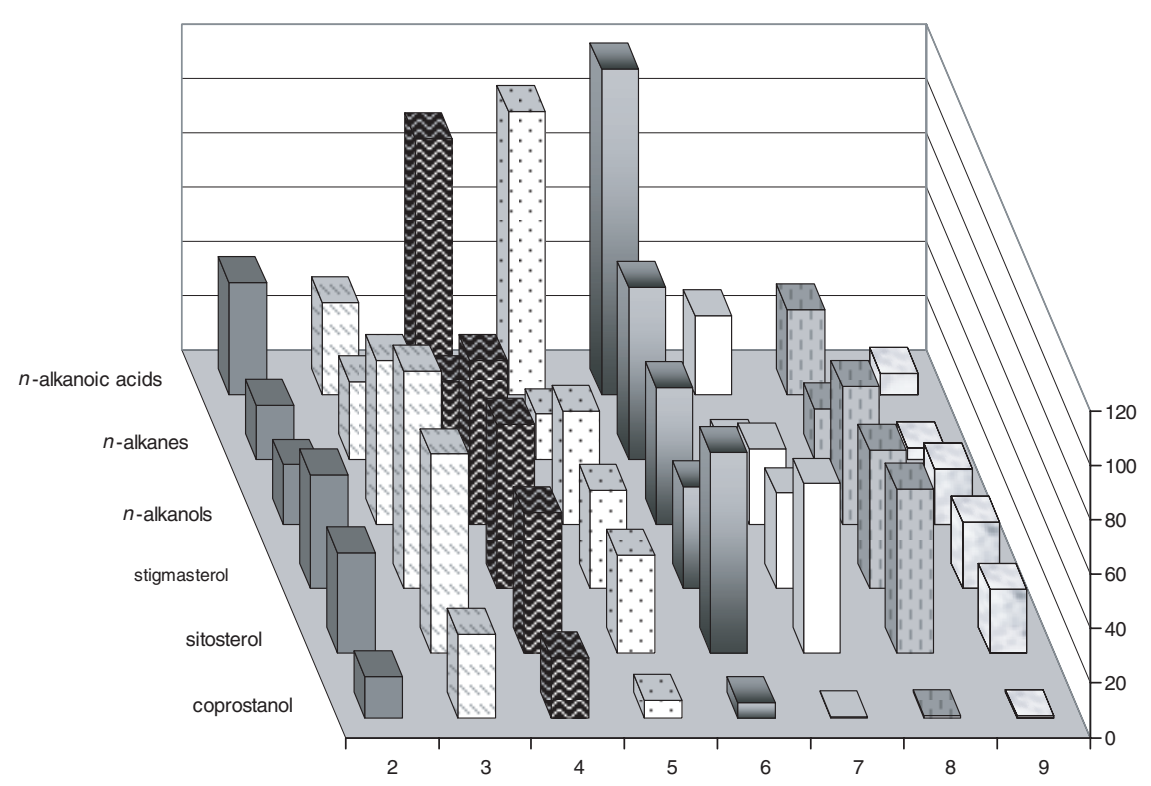

Fig. 3. Percentage of terrestrial organic carbon associated with different markers in the mixing zone and open seawaters at station 9 of a leg off the Sulina branch of the Danube delta (salinity = 15.5) with respect to terrestrial organic carbon in the river at station 1 (salinity $=0.3)$. Salinity increases from station 2 (1.6) to stations 3 (2.9), 4 (4.8), 5 (8.6), 6 (10.2), 7 (12.4), 8 (14.8) and 9 (15.5). From Saliot et al. [10].

2.1.2.5 Comparing informations from different source markers at the Danube/Black Sea interface. In a comprehensive study of the transport and fate of Danube Delta terrestrial organic matter in the Northwest Black Sea mixing zone Saliot et al. $[10,17]$ showed that in the northwestern Black Sea the carbon cycle is dominated by riverine inputs carried out in spring off the Sulina branch of the Danube Delta. The distribution of particulate organic carbon, Chlorophyll $a$ and $\delta^{13} \mathrm{C}$ evidenced an omni-present contribution of terrestrial organic matter throughout the study area together with a dilution of these inputs by freshwater and marine organisms. Several signature compounds were selected to delineate dispersion of terrestrial organic carbon associated with particles and present in the dissolved phase 1) long-chain $n$-alkanoic acids in the range $\mathrm{C}_{24}-\mathrm{C}_{34}$, long-chain $n$-alkanes in the range $\mathrm{C}_{25}-\mathrm{C}_{35}$, long-chain $n$-alkohols in the range $\mathrm{C}_{22}-\mathrm{C}_{30}, 24$-ethylcholesta- 5,22 -dien- $3 \beta$-ol $\left(29 \Delta^{5,22}\right.$ or stigmasterol) and 24-ethylcholesterol $\left(29 \Delta^{5}\right.$ or sitosterol) for vascular plant-derived material and coprostanol, a marker for sewage effluents. A marked decrease was observed for particles between the concentrations of different vascular plant markers characterizing the two end-members: riverine at salinity 0.3 and marine at salinity 15.5. The decrease observed for marine/riverine end-members (expressed as a function of organic carbon) varied in a large range, from $4 \%$ for $n$-alkanes to $18.6 \%, 20.4 \%$ and $24 \%$ for $n$-fatty acids, $n$-alkanols and sterols, respectively (Fig. 3 ). These values reflect a combination of various processes: size-selective particle sedimentation, resuspension of different particle pools of different sizes and ages and/or selective biological utilization. The multi-marker approach also suggested the liberation in the mixing zone of terrestrial moieties, tightly trapped in macromolecular structures of the riverine material. The greatest decrease for marine/riverine end-members was observed for coprostanol $(0.9 \%)$, underlining the efficiency of the mixing zone as a sink for sewage-derived carbon.

\subsection{Macromolecular compounds of higher plants}

Both the woody and non woody tissues of higher plants contain abundant and diverse macromolecular compounds, including cutin, lignin, cellulose and various resins. Some of these are 
<smiles>O=C(O)/C=C/c1ccc(O)cc1</smiles>

V<smiles>COc1cc(C(=O)O)ccc1O</smiles>

VI<smiles>COc1cc(C(=O)O)cc(OC)c1O</smiles>

VII

Fig. 4. Structures of lignin monomers as acids. V: 4-OH-cinnamic acid; VI: vanillic acid; VII: syringic acid.

useful for environmental reconstruction. One of the most powerful methods for tracking different types of terrestrial organic carbon throughout the environment has been cupric oxide oxidation, a technique that gently breaks large bio- and geo-polymers into smaller units that are then analysed by gas chromatography [6,7]. The method is most commonly used to determine the concentrations of various lignin phenols which are used as tracers of vascular plantderived organic carbon in marine sediments and soils (Fig. 4). Other compounds released upon cupric oxide oxidation have been used as biomarkers for cutin, proteins, polysaccharides and lipids [18]. Abundances of the phenolic components of lignin, obtained by cupric oxide oxidation of sediments have been used to assess terrestrial inputs (distinguishing inputs from nonwoody angiosperms, woody angiosperms and woody gymnosperms) to marine sediments [6] and waters [19]. However, interpretation of such ratios should be done cautiously, as syringyl and cynnamyl phenols are more reactive than vanillyl phenols.

Terrigenous organic matter sources in both particles and dissolved phase, and reactivity were studied in Atlantic, Arctic and Pacific oceans by Hernes and Benner [19]. Samples were analysed for lignin phenol concentrations and compositions together with $\delta^{13} \mathrm{C}$ of particulate organic carbon. Carbon normalized yields of lignin phenols and $\delta^{13} \mathrm{C}$ measurements of particles indicated that up to half of the suspended material in deep water was of terrigenous origin and appeared to enter the ocean via atmospheric deposition. In contrast to particulate organic matter, dissolved organic matter lignin phenol concentrations were $\sim 2$-fold higher in the Atlantic, with more than two thirds in the high-molecular weight (>1000 Da) fraction. Elevated concentrations of dissolved lignin phenols in North Atlantic Deep Water (NADW) indicated that 10-16\% of annual fluxes of terrigenous dissolved organic matter from Arctic rivers could be entrained during NADW formation. The percentage of lignin phenols in the high molecular weight fraction decreased progressively from the Arctic to Atlantic to Pacific Oceans, reflecting an increasing diagenesis of terrigenous organic matter. Calculations showed that the average residence time of lignin phenols in the Atlantic was $\sim 35$ years and that terrigenous organic carbon accounted for 1-2\% of the dissolved organic carbon in surface and deep waters of the North Atlantic.

Cupric oxide oxidation also releases a number of benzene carboxylic acids (BCAs). It has been suggested that some BCAs might derive from charcoal making them a potentially tracer of combustion-derived organic carbon in the environment. Recently Dickens et al. [20] analyzed the concentrations of an extended suite of 18 BCAs from over 75 samples. Both terrestrial and marine samples yielded the suite, whereas charcoal did not appear to control the total BCA yield. Types of organic carbon produced by marine biota (i.e. glucose, protein and degraded phytoplankton) produce many of the BCAs, but not 3,5-dihydroxybenzoic acid, suggesting that previous applications of this compound for tracing soil organic carbon in the ocean may be robust.

Other methods appear as promising: Curie-point pyrolysis-gas chromatography (CuPy-GC) and Cury-point-gas chromatography-mass spectrometry, were used to characterize the macromolecular organic content of suspended particles in surface waters, at intermediate depths, and 
<smiles>CC(C)C1=CC2=CC[C@H]3[C@](C)(C(=O)O)CCC[C@]3(C)C2CC1</smiles>

VIII<smiles>Cc1cccc2c1ccc1cc(C(C)C)ccc12</smiles>

IX

Fig. 5. Structures of abietic acid (VIII) and retene (IX).

in surface sediments of the Lena Delta and adjacent Laptev Sea, eastern Siberia, by Peulvé et al. [21]. The chromatograms of the Lena River particles revealed several compound classes of biogenic significance: polysaccharides, phenolic substances and lipid constituents of higher plants. The pyrolysates of the surface-suspended particles of the Laptev Sea showed mixed inputs. Some n-alkanoic acids, phytadienes and n-alkylnitriles were assigned to planktonic organisms. Pyrolysis products from terrigenous material encountered in the river were also present. The composition of the sedimentary material in the Laptev Sea indicated preservation of the refractory terrigenous constituents. However the presence of some algal constituents suggested that a fraction of marine-derived macromolecules was resistant to degradation.

Thermochemolysis with tetramethyl ammonium appeared as a promising tool, used by Garcette-Lepecq et al. [22] for evidencing tightly-bound n-alkanoic acids in Black Sea sediments. Ishiwatari et al. [23] also used this analytical approach in Lake Baikal sediments for evidencing lignin phenols, n-alkanoic acids, cutin acids, hydroxyacids and aliphatic dicarboxylic acids.

\subsection{Biomarkers for biomass burning}

Some compounds are useful in recording terrestrial processes such as biomass burning. Biomass burning introduces into the atmosphere and ultimately soils and sediments a range of compounds, many of which are indistinguishable from those associated with natural weathering such as n-alkyl compounds or fossil fuel use such as polycyclic aromatic compounds. Exceptions exist such as retene, a polycyclic aromatic hydrocarbon derived from the dehydrogenation of abietic acid, a diterpenoid particularly abundant in resins of conifers in temperate climates (Fig. 5). Thus retene may be used as a unique molecular marker of wood combustion from coniferous vegetation as suggested by Ramdahl [24].

In the open western Mediterranean Sea, retene has been identified in sediments [25] and in aerosols [13]. Retene has been also identified in air samples collected over the North Pacific Ocean and the Arctic Ocean [26].

Other biomarkers have been proposed and utilized to be diagnostic for biomass burning $[27,28]$. Monosaccharide derivatives from the breakdown of cellulose have been identified as the major organic components of smoke particles from biomass burning. Cellulose decomposes on heating or on exposure to an ignition source by two possible pathways. The first dominates at temperatures below $300^{\circ} \mathrm{C}$ and yields ultimately to char formation. The second pathway occurs at temperatures above $300^{\circ} \mathrm{C}$ and yields cellulose-specific molecular tracers, mainly the 1,6 anhydride of glucose known as levoglucosan isomer and a dianhydride (Fig. 6).

Critically, levoglucosan and other relative cellulose pyrolysis products in natural settings appear to have no other significant source and are specific of the burning of cellulose containing fuels. Levoglucosan and related compounds have been found in significant amounts in atmospheric samples from over the Atlantic Ocean [30], confirming the long-range transport of smoke from the continents, as well as lacustrine and marine sediments. Another validation for the use of levoglucosan as a biomarker burning is given by similar records of charcoal and levoglucosan observed in sediments from lake Carajas (south eastern Amazonia) over the past 7000 years [31]. 


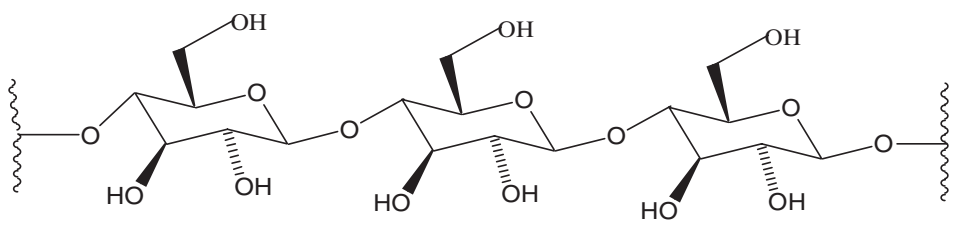

$\mathbf{X}$

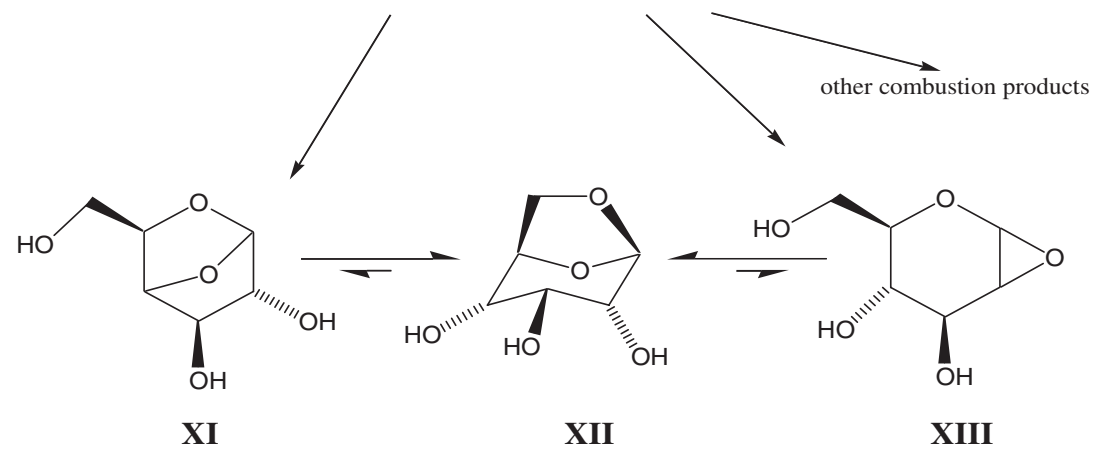

Fig. 6. Pathways of cellulose combustion leading to the formation of levoglucosan, 1,6-anhydro- $\beta$ gluco-pyranose (XII). XI: 1,4 anydride; XIII: 1,2 anydride, from [29].

\section{Perspectives}

Other biomarkers exist to track terrestrial inputs and transport mechanisms. I selected a nice article from Schouten et al. [32]. The authors used the analysis of glycerol dialkyl glycerol tetraethers (GDGTs) in sediments from the North Atlantic covering the last $30 \mathrm{kyr}$ to investigate deposition due to ice rafting.

The systematic relationship between plant n-alkyl compounds can be useful to compare isotopic records different n-alkyl compounds in various environmental samples. This domain has been explored by Chikaraishi and Naraoka [33]. For this purpose carbon $\left(\delta^{13} \mathrm{C}\right)$ and hydrogen $(\delta \mathrm{D})$ isotopic compositions of long-chain n-alkanoic acids, n-alkanes and n-alkohols from plant leaves including C3 angiosperm, C3 gymnosperm, C4 and CAM plants were determined in order to clarify detailed isotopic relationships among the three classes of n-alkyl compounds in terrestrial higher plants. For all plant species, the three classes of n-alkyl compounds have a similar range of $\delta^{13} \mathrm{C}$ and $\delta \mathrm{D}$ values within a single species. However, most plants showed a small but significant systematic difference in both $\delta^{13} \mathrm{C}$ and $\delta \mathrm{D}$ values with respect to biosynthetically corresponding carbon-numbered compounds.

Rommerskirchen et al. [34] studied the distribution patterns and molecular stable isotopic compositions of long-chain n-alkanes $\left(n-C_{27}\right.$ to $\left.n-C_{35}\right)$ and n-alkohols $\left(n-C_{22}\right.$ to n- $\left.C_{32}\right)$ to estimate the chemotaxonomic relevance of wax signatures of C3 and C4 grasses from the southern African tropical and subtropical savannas and deserts. A preliminary assessment was made of the reliability ox wax homologues as proxy parameters by evaluating the contribution of different parts of two grass species to the whole plant wax signal.

\section{References}

1. K.L. Denman, G. Brasseur, A. Chidthaisong, P. Ciais, P.M. Cox, R.E. Dickison, D. Hauglustaine, C. Heinze, E. Holland, D. Jacob, U. Lohmann, S. Ramachandran, P.L. da Silva Dias, S.C. Wofsy, X. Zhang, in Climate Change 2007: The Physical Science Basis. Contribution of Working Group I to the Fourth Assessment Report of the Intergovernmental Panel on Climate Change, edited by S. Solomon, D. Qin, M. Manning, Z. Chen, M. Marquis, K.B. Averyt, M. Tignor, H.L. Miller (Cambridge University Press, Cambridge, 2007), p. 499

2. J.I. Hedges, Mar. Chem. 39, 67 (1992) 
3. A. Saliot, J. Phys. IV (France) 139, 201 (2006)

4. E.M. Galimov, Org. Geochem. 37, 1200 (2006)

5. R.D. Pancost, C.S. Boot, Mar. Chem. 92, 239 (2004)

6. J.I. Hedges, D.C. Mann, Geochim. Cosmochim. Acta 43, 1803 (1979)

7. T.I. Eglinton, G. Eglinton, L. Dupont, E.R. Sholkovitz, D. Montlucon, C.M. Reddy, Geochem. Geophys. Geosys. 3, 1 (2002)

8. A. Saliot, J. Laureillard, P. Scribe, M.-A. Sicre, Mar. Chem. 36, 233 (1991)

9. J.K. Volkman, S.M. Barrett, S.I. Blackburn, M.P. Mansour, E.L. Sikes, F. Gelin, Org. Geochem. 29, 1163 (1998)

10. A. Saliot, C.C. Parrish, N. Sadouni, I. Bouloubassi, J. Fillaux, G. Cauwet, Mar. Chem. 79, 243 (2002)

11. W. Rogge, P.M. Medeiros, B.R.T. Simoneit, Atmos. Environ. 41, 8183 (2007)

12. B.R.T. Simoneit, Mar. Chem. 5, 443 (1977)

13. M.-A. Sicre, J.C. Marty, A. Saliot, X. Aparicio, J. Grimalt, J. Albaigés, Atmos. Environ. 21, 2247 (1987)

14. C. Treignier, S. Derenne, A. Saliot, Org. Geochem. 37, 1170 (2006)

15. E.J. Waterson, E.A. Canuel, Org. Geochem. 39, 422 (2008)

16. J.K. Volkman, A.T. Revill, D.G. Holdworth, D. Fredericks, Org. Geochem. 39, 689 (2008)

17. A. Saliot, S. Derieux, N. Sadouni, I. Bouloubassi, J. Fillaux, J. Dagaut, A. Momzikoff, G. Gondry, C. Guillou, O. Breas, G. Cauwet, G. Deliat, Estuar. Coast. Shelf. Sc. 54, 355 (2002)

18. M.A. Goñi, J.I. Hedges, Geochim. Cosmochim. Acta 59, 2965 (1995)

19. P.J. Hernes, R. Benner, Mar. Chem. 100, 66 (2006)

20. A.F. Dickens, J.A. Gudeman, Y. Gélinas, J.A. Baldock, W. Tinner, F.S. Hu, J.I. Hedges, Org. Geochem. 38, 1256 (2007)

21. S. Peulvé, M.-A. Sicre, A. Saliot, J.W. De Leeuw, M. Baas, Limnol. Oceanogr. 41, 488 (1996)

22. A. Garcette-Lepecq, C. Largeau, I. Bouloubassi, S. Derenne, A. Saliot, A. Lorre, V. Point, Org. Geochem. 35, 959 (2004)

23. R. Ishiwatari, S. Yamamoto, S. Shinoyama, Org. Geochem. 37, 1787 (2006)

24. T. Ramdahl, Nature 306, 580 (1983)

25. E. Lipiatou, A. Saliot, Mar. Chem. 32, 51 (1991)

26. X. Ding, X.-M. Wang, Z.-Q. Xie, C.-H. Xiang, B.-X. Mai, L.-G. Sun, M. Zheng, G.-Y. Sheng, J.-M. Fu, U. Pöschl, Atmos. Environ. 41, 2061 (2007)

27. B.R.T. Simoneit, Appl. Geochem. 17, 129 (2002)

28. J.G. Su, M. Buzzelli, M. Brauer, T. Gould, T.V. Larson, Atmos. Environ. 42, 5519 (2008)

29. B.R.T. Simoneit, J.J. Schauer, C.G. Nolte, D.R. Oros, V.O. Elias, M.P. Fraser, W.F. Rogge, G.R. Cass, Atmos. Environ. 33, 173 (1999)

30. B.R.T. Simoneit, V.O. Elias, Mar. Chem. 69, 301 (2000)

31. V.O. Elias, B.R.T. Simoneit, R.C. Cordeiro, B. Turcq, Geochim. Cosmochim. Acta 65, 267 (2001)

32. S. Schouten, J. Ossebaar, G.J. Brummer, H. Elderfield, J.S. Sinninghe Damsté, Org. Geochem. 38, 1161 (2007)

33. Y. Chikaraishi, H. Naraoka, Org. Geochem. 38, 198 (2007)

34. F. Rommerskirchen, A. Plader, G. Eglinton, Y. Chikaraishi, J. Rullkötter, Org. Geochem. 37, 1303 (2006) 
